\title{
A new variety of Abelmoschus pungens (Malvaceae) from Indo-Burma Biodiversity Hotspot
}

\author{
John J.K. ${ }^{1}$, Krishnaraj M.V. ${ }^{2 *}$, Pradheep K. ${ }^{1}$, Patil P. ${ }^{3}$, Harish G.D. ${ }^{4}$ \& K.V. Bhat ${ }^{5}$ \\ ${ }^{1}$ ICAR - National Bureau of Plant Genetic Resources, Regional Station, Thrissur, Kerala - 680 656, India. \\ ${ }^{2}$ Department of Botany, Baselius College, Kottayam, Kerala - 686001 , India. \\ ${ }^{3}$ Department of Botany, Shankarlal Agrawal Science College, Salekasa, Maharashtra - 441916 , India. \\ ${ }^{4}$ ICAR - National Bureau of Plant Genetic Resources, Regional Station, Shillong - 793 103, India. \\ ${ }^{5}$ ICAR - National Bureau of Plant Genetic Resources, Pusa Campus, New Delhi - 110 012, India. \\ *E-mail: krishnarajtbgri@gmail.com; krishnarajmv@baselius.ac.in
}

\begin{abstract}
A new variety of Abelmoschus pungens (Roxb.) Wall. ex Voigt, viz., A. pungens var. mizoramensis K.J.John, Krishnaraj \& K.Pradheep is described from Mizoram, Northeast India and the species status of $A$. pungens is also discussed.
\end{abstract}

Keywords: Abelmoschus pungens var. mizoramensis, $A$. tetraphyllus, Genetic resources of okra, Mizoram.

\section{Introduction}

The Indian subcontinent deserves to be considered as the center of diversity of the genus Abelmoschus Medik. due to the presence of a high number of species and wide morphological variations. Most of the cultivated and wild species are spread across various phyto-geographical regions of the Himalayas to southern peninsular India. A. manihot (L.) Medik. is a cultivated leafy vegetable occurring in Southeast Asia, characterized by shy fruiting but propagated by stem cuttings (Ochse \& Bakhuizen van den Brink, 1931). Abelmoschus esculentus (L.) Moench (okra) and A. caillei (A.Chev.) Stevels (Guinean okra) are cultivated for immature fruits and used as vegetables and $A$. moschatus Medik. is cultivated as an aromatic seed crop. Taxonomic description and designation of morphological variants are important from a conservation and utilization points of view.

Received: 15.04.2020; Revised \& Accepted: 14.10.2020

Published Online: 31.12.2020 van Borssum Waalkes (1966) in his revision of the genus, retained only six species in Malesia, viz., $A$. manihot, A. moschatus, A. ficulneus (L.) Wight \& Arn. ex Wight, $A$. angulosus Wall. ex Wight \& Arn., $A$. crinitus Wall. and $A$. esculentus. He followed the broader species concept of Hochreutiner (1924) and treated A. tetraphyllus and A. pungens as infraspecific taxa of $A$. manihot. This treatment was followed by Paul and Nayar (1988) and Paul (1993) in their work on the Flora of India for the family Malvaceae. Subsequently, Sivarajan and Pradeep (1996) subsumed both the infraspecific taxa (tetraphyllus and pungens) under the broad species, A. manihot, citing feeble and highly variable characters used for their distinction. However, their study was based on specimens housed at BLAT and $\mathrm{MH}$ only; these herbaria rarely house specimens from Himalayan and Northeast India, where only A.pungens occurs in the wild.

It was Wallich (1829), who considered A. pungens as a distinct species (as nomen nudum). Later Voigt (1845) made a legitimate combination by placing Hibiscus pungens of Roxburgh (1832) under Abelmoschus, i.e., A. pungens (Roxb.) Wall. ex Voigt. Subsequently, A. tetraphyllus (Roxb. ex Hornem.) R. Graham, A.tuberculatus Pal \& Har. B. Singh and $A$. caillei were accepted as valid species (Anonymous, 1991). Recently two new species viz., A. enbeepeegearensis K.J.John et al. (John et al., 2013), A. palianus Sutar et al. (Sutar et al., 2013) and a new variety of $A$. angulosus viz., A. angulosus var. 
mahendragiriensis R.C.Misra (Misra et al., 2018) were described from India. Based on unique morphological traits and specific geographic distribution, we support Voigt's view of distinct species status for $A$. pungens, independent of $A$. tetraphyllus and $A$. manihot. Biosystematic studies (Yadav et al., 2014), especially seed micromorphological characters (Patil et al., 2015a) support the taxonomic elevation of $A$. manihot subsp. tetraphyllus var. pungens to species level. Presently there are 11 species, 3 subspecies and 5 varieties of Abelmoschus in India (Yadav et al., 2014; Patil et al., 2015b; Misra et al., 2018).

\section{Materials and Methods}

During the biosystematic studies on the genus Abelmoschus in India, extensive explorations were conducted in northeastern states of Sikkim, Arunachal Pradesh, Mizoram, Tripura, Meghalaya, Nagaland and Assam which yielded distinct wild forms, allied to $A$. pungens. The collected specimens were compared with those available in CAL, DD, $\mathrm{MH}, \mathrm{BSI}, \mathrm{BSINC}$ and ASSAM and seeds were grown out in the field along with 160 accessions representing 11 species. Based on morphological characterization, we arrive at the conclusion that the Mizoram populations are a new entity hitherto undescribed warranting a varietal status, the same is described herein under the name $A$. pungens var. mizoramensis K.J.John., Krishnaraj \& K.Pradheep var. nov. A detailed description of $A$. pungens var. pungens is also provided for better comparison in the field.

\section{Taxonomic treatment}

\section{Key to the varieties of $A$. pungens}

1. Flowers solitary and axillary or in lax terminal racemes; epicalyces 4, deltoid, keeled, more or less covering the whole mature fruit

var. pungens

1. Flowers in rosette appearance at the top; epicalyces 6(7), ovate or elliptic-lanceolate, not keeled, less than half the length of mature fruit var. mizoramensis
Abelmoschus pungens (Roxb.) Wall. ex Voigt var. pungens Hort. Suburb. Calcutt. 119. 1845. Hibiscus pungens Roxb. Fl. Ind. 3. 213. 1832; Merr., Enum. Philipp. Fl. Pl. 3: 41. 1923. A manihot var. pungens (Roxb.) Hochr., Candollea 2: 87. 1924; Tang et al. in Wu \& Raven, Fl. China 12: 283. 2007; Hsieh et al., Taiwania 58: 119. 2013. Lectotype (designated by van Borssum Waalkes, 1966): INDIA, Botanic Garden Calcutta, Roxburgh s.n. (BR [BR 00000517969 digital image!) $\quad$ Figs. 1 \& 2

Erect, 5-7 branched from base, sub-perennial undershrubs, 2-4 m tall. Roots non-tuberous. Stems green, turning brown at maturity, round, fistular, purplish spots present on younger parts, hispid, glabrescent on basal region only; hairs simple, finely silvery, unequal, stiff, retrorse, 3-5 mm long. Stipules c. $1.8 \times 0.1 \mathrm{~cm}$, linear-lanceolate, or ensiform, narrowly acute, caducous, silvery ciliate on the margins, green. Leaves variable in size and shape; petioles terete, $8-16 \mathrm{~cm}$ long, sparsely hirsutellous, greenish when young, purple-tinged throughout at maturity. lamina $7(-10)-12(-16) \times$ $3(-5)-5(-8) \mathrm{cm}$, densely hispid, 5-7 deeply lobed throughout, cordate at base, unevenly dentate along the margins, acuminate at apex; hairs on upper surface simple, silvery, straight, unequal and stiff, hairs on lower surface stellate, stiff, easily detachable. Flowers solitary or arranged in axillary lax racemes, clustered at top without a rosette appearance; pedicels 1.1-1.5 cm long, sparsely hispid. Epicalyx 4-lobed, green; lobes deltoid, $2.6-3 \times 1-1.8 \mathrm{~cm}$, narrowly acute at apex, touching each other at bud stage, showing a keeled appearance, prominently nerved, persistent, clasping the fruit, covering full and bent downwards on drying, sparsely ciliate with unequal hairs throughout. Calyx spathaceous, c. $3 \times 1.9 \mathrm{~cm}$; sepals 5 , caducous, split in to $3+2$ during anthesis, sericeous on both sides, shortly ciliate, cilia longer at the apex. Corolla bright yellow with a central purple eye, 10-14 cm across; petals 5, obovate, 4-4.5 × 2.9$3.3 \mathrm{~cm}$, rounded at apex, base fleshy with a purple blotch, glabrous, shortly ciliate. Staminal column $c$. $1.8 \times 0.2 \mathrm{~cm}$, yellowish, antheriferous throughout, glabrous; anthers yellow, reniform, dorsifixed, dehiscing longitudinally, extrorse, monothecous. 


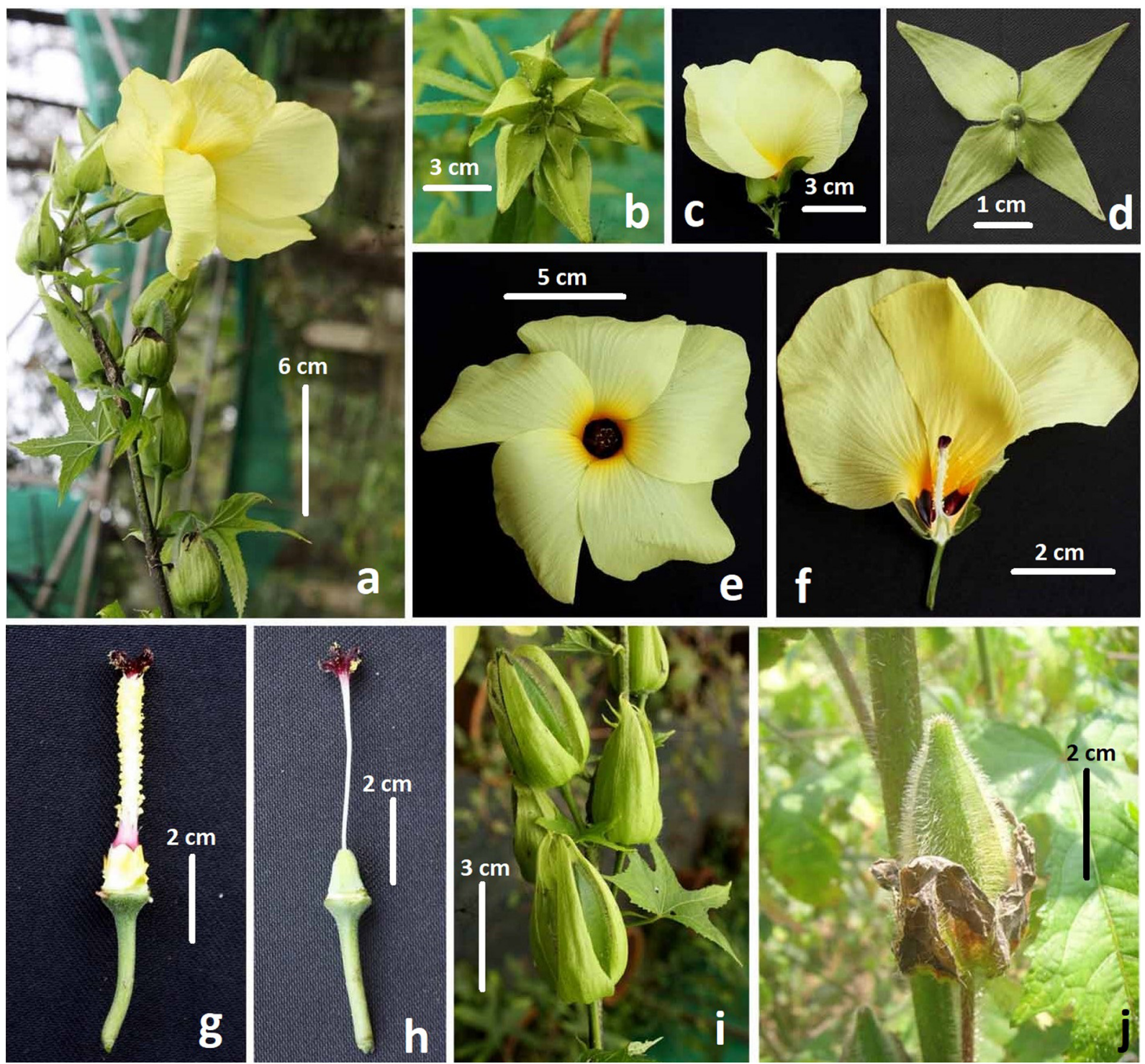

Fig. 1. Abelmoschus pungens (Roxb.) Wall. ex Voigt var. pungens: a. Habit; b. Flower buds; c. Flower - side view; d. Epicalyx; e. Flower - front view; f. L.S. of flower; g. Staminal column; h. Gynoecium; i \& j. Fruits (from IC253297; photos by J.K. John, K. Pradheep \& G.D. Harish).

Ovary c. $5 \times 3.5 \mathrm{~mm}$, ovate, densely appressed velutinous; style single, $2-2.3 \mathrm{~cm}$ long, not prolonged beyond the anther column, glabrous, apex purple in colour; stigma dark maroon, deeply divided in to five segments, clavate, $c .0 .5 \times 0.3 \mathrm{~cm}$. Capsules ovoid-ellipsoid, c. $4.5 \times 1.5 \mathrm{~cm}$ less wider at base, 5 costate, between the costae prominently concave, bristly hispid throughout, green, turning greyish black when dry, acuminate with 2-3 mm long rostrum, dehiscing apically downwards; hairs $c .3$ $\mathrm{mm}$ long, tawny. Seeds 35-62, reniform, c. $2 \times 2$ $\mathrm{mm}$, sub-puberulous on concentric warty rings; hilum c. $1 \times 1 \mathrm{~mm}$, ovate, glabrous.
Flowering \& fruiting: Flowering from September to October; fruiting from September to December.

Distribution: Himalaya, Northeast India, extending to Indo-China.

Specimens examined: INDIA, Sikkim, West Sikkim district, Chakung, 1540 m, 14.11.1981, B. Krishna 1793 (CAL); Rumara, s.d., T. Thomson s.n. (CAL). North West Himalayas, s.d., Mackinnon s.n. (CAL); Uttarakhand, Kumaon, Nainital, Jeolikote, 4000 ft, 03.09.1912, N. Gill 405 (CAL); Kumaon, Gora Valley, Sheraghat, 26.08.1900, Inayat 24278 (CAL); Nainital, October 1905, Meebold 3705 (CAL). 


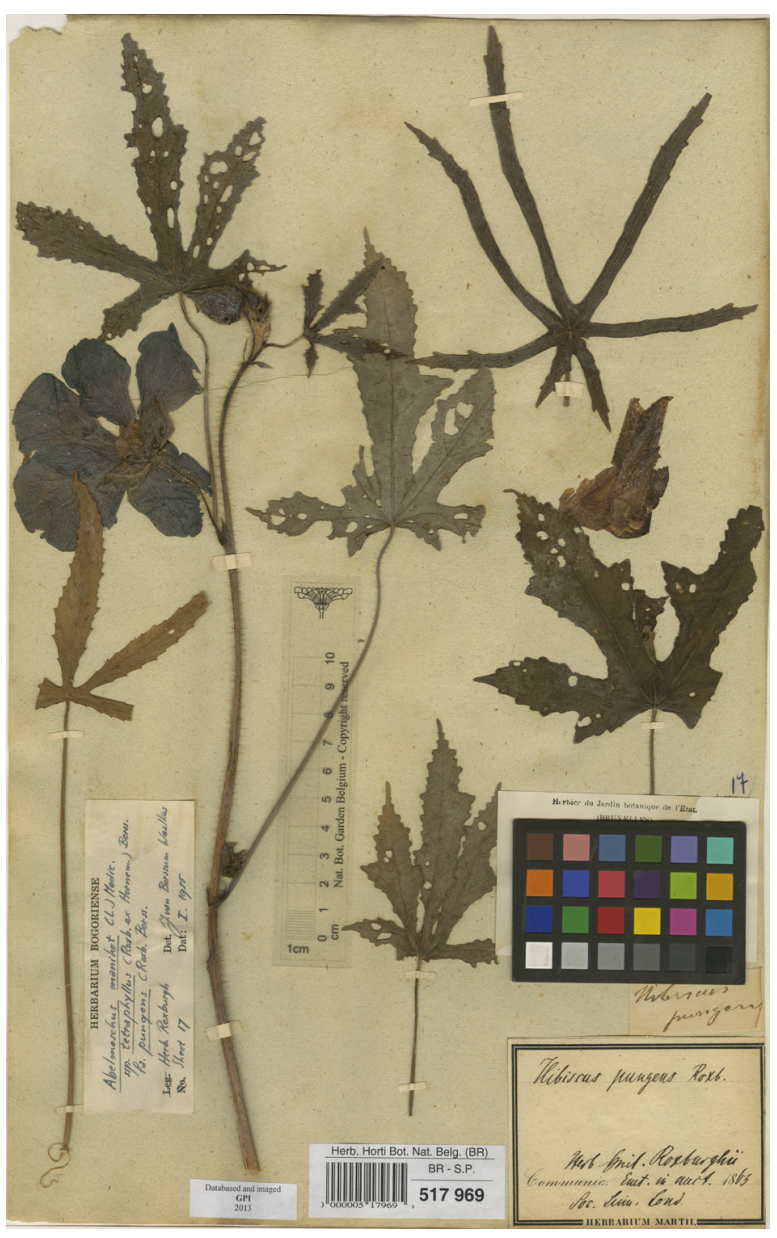

Fig. 2. Lectotype of Hibiscus pungens Roxb. (C) Meise Botanic Garden, Belgium. Reproduced with permission.

\section{Abelmoschus pungens var. mizoramensis K.J.John, Krishnaraj \& K.Pradheep, var. nov.}

Fig. 3

Similar to var. pungens, but distinguished by flowers in rosette appearance at the top, 6 or 7, ovate or elliptic-lanceolate epicalyces, without keel, covering less than half the fruit length, and the fruit being 6-7.2 × 2.5-2.8 cm with a broad base.

Type: INDIA, Mizoram, Kolasib district, Tuithveng, 14.10.2011, Joseph John JJK/11-1 (holo $\mathrm{NHCP!}$; iso CAL!).

Erect, perennial, robust undershrubs, c. $3 \mathrm{~m}$ tall, 23 branched from base. Roots non-tuberous. Stems green, round, fistular, young stem finely purple spotted, dark-purple blotched at nodes, blotches extending to internodes, hispid, glabrescent on basal region only; hairs simple, fine silvery shining, unequal, stiff, retrorse, c. $5 \mathrm{~mm}$ long. Stipules green, linear-lanceolate, c. $2.8 \times 0.3-0.5 \mathrm{~cm}$, semipersistent, ciliate, one on each side, narrowly acute, sparsely pubescent on both sides; cilia 4-5 mm long. Leaves variable in size and shape; petioles 18-20 cm long, greenish, junction often purple, sparsely hairy towards base, densely hairy towards apex, hairs at junction directed downwards; hairs c. $5 \mathrm{~mm}$ long; lamina 5-angular or shallowly 7-lobed towards the base of stem and new branches, not deeply lobed towards apex, densely hispid; lower leaves broadly orbicular in outline, 15-36 × 24-40 $\mathrm{cm}$; upper leaves $5-7 \times 4-8 \mathrm{~cm}$ or less, palmatifid, cordate at base, dentate along the margins, acuminate at apex; hairs on upper surface simple, silvery, straight, unequal and stiff, hairs on lower surface stellate, stiff, easily detachable by stinging on body. Flowers solitary, axillary, appear as a rosette of flower buds and stipules at top. Pedicels $2-3.5 \mathrm{~cm}$ long, accrescent, up to $7 \mathrm{~cm}$ long in fruit, densely hispid throughout. Epicalyx 6(7)-lobed, green, sometimes purple spotted, persistent; lobes ovate or elliptic-lanceolate, cymbiform, c. $3.5 \times 0.5-$ $1.2 \mathrm{~cm}$ (width varies with respect to epicalyx number), narrowly acute at apex, not touching each other, not showing a keeled appearance, profusely pubescent on upper and lower surface, clasping in fruit, covering not more than half the length of fruit and bent downwards on drying, densely ciliate on the margins; hairs 2-4 mm long. Calyx spathaceous, caducous; sepals $5,2.5-2.9 \times 2.6-2.9 \mathrm{~cm}$, split in to $3+2$ during anthesis, sericeous on both sides, minutely ciliate along the margins. Corolla bright yellow with a central purple eye, $13.5-14.5 \mathrm{~cm}$ across; petals 5, obovate, 7-8 $\times 4.8-6.2 \mathrm{~cm}$, rounded at apex, base fleshy with a purple coloration, glabrous. Staminal column c. $2.2 \times 0.3 \mathrm{~cm}$, yellowish, antheriferous throughout, glabrous; anthers yellow, reniform, dorsifixed, dehiscing longitudinally, extrorse, monothecous. Ovary ovoid or conical, c. $0.7 \times 0.6 \mathrm{~cm}$, densely appressed velvety; style single, prolonged beyond anther column, glabrous, $2.3-2.5 \mathrm{~cm}$ long, apex purple in colour, dilated; stigma dark maroon, c. $0.5 \times 0.3$ 

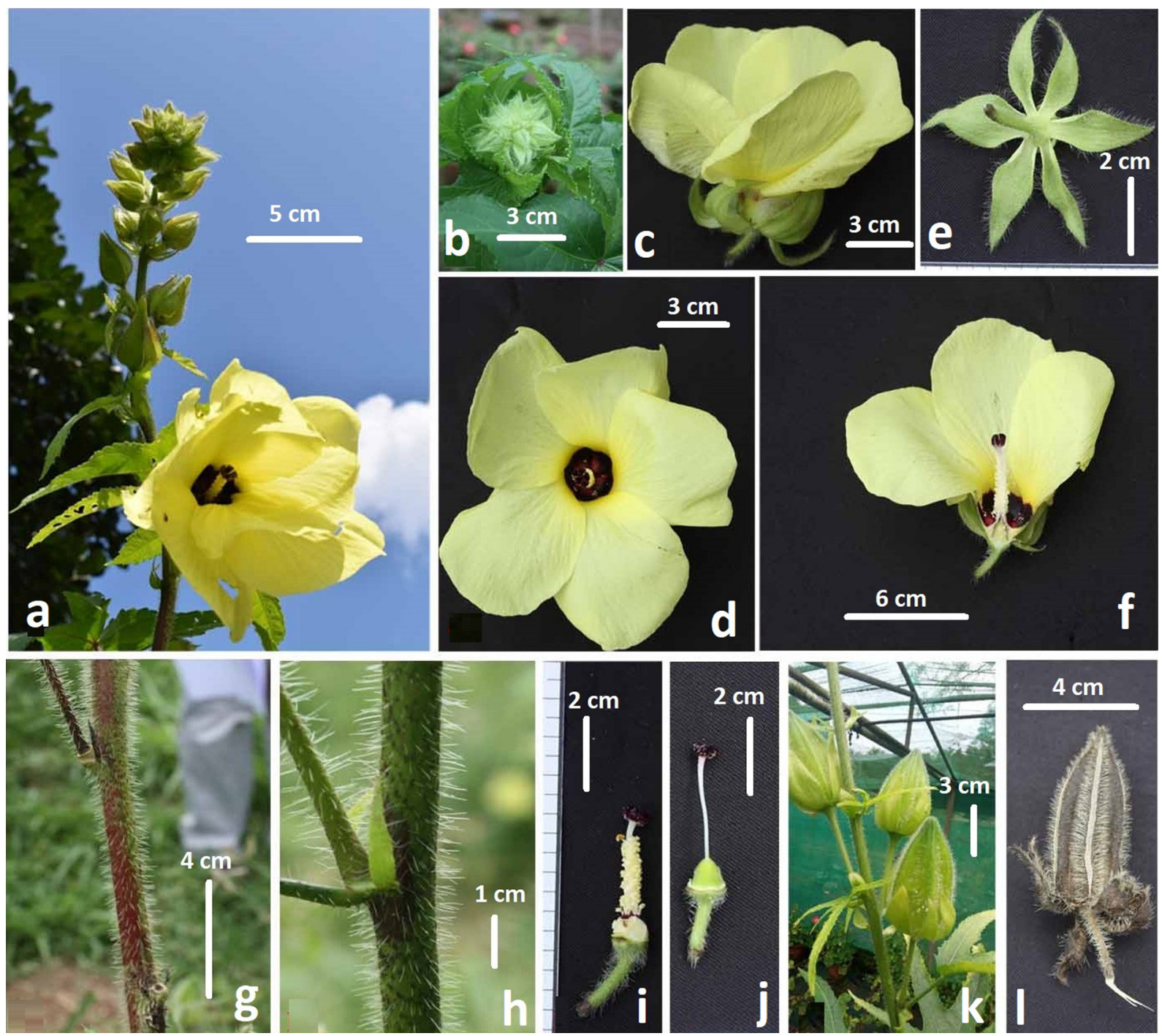

Fig. 3. Abelmoschus pungens var. mizoramensis K.J.John, Krishnaraj \& K.Pradheep, var. nov.: a. Habit; b. Flower buds; c. Flower - side view; d. Flower - front view; e. Epiclayx; f. L.S. of flower; g. Internode showing indumentum; h. Stipule; i. Staminal column; j. Gynoecium; k \& I. Fruits (from Joseph John JJK/11-1; photos by K. Pradheep \& G.D. Harish).

$\mathrm{cm}$, deeply divided in to five segments, each segment capitate. Capsules ovoid, c. 6-7.2 × 2.5$2.8 \mathrm{~cm}, 5$-costate, broad at base, between the costae prominently concave, bristly hispid throughout, parrot-green, turning greyish black when dry, acuminate with 2-4 $\mathrm{mm}$ long rostrum, dehiscing apically downwards; hairs 4-5 mm long, tawny. Seeds sub-reniform, c. $3.7 \times 2.8 \mathrm{~mm}$, subpuberulous on concentric warty rings; hilum $c .2 \times$ $1 \mathrm{~mm}$, ovate, glabrous.

Flowering \& fruiting: Flowering from July to September; fruiting from October to December. At higher elevations (>500 m), maturity is delayed by a month. Best time for collection of seeds is between mid or end of November to last week of December.

Habitat: A. pungens var. mizoramensis occurs at an altitude between 150 to $800 \mathrm{~m}$, in association with Solena heterophylla Lour., Trichosanthes sp., Thladiantha cordifolia Cogn.(Cucurbitaceae), Solanum violaceum Ortega (Solanaceae), Musa balbisiana Colla (Musaceae), etc. Generally observed on the edges of secondary forests, roadsides, grasslands and forest slopes. Common in Lunglei and Serchhip, and occasional in Kolasib, Aizwal and Lwangtlai districts. 
Table 1. Comparison of A. pungens var. pungens, A.pungens var. mizoramensis and A. tetraphyllus.

\begin{tabular}{|c|c|c|c|}
\hline Characters & $\begin{array}{l}\text { A. pungens (Roxb.) } \\
\text { Wall. ex Voigt var. pungens }\end{array}$ & $\begin{array}{l}\text { A. pungens var. mizoramensis } \\
\text { K.J.John, Krishnaraj \& } \\
\text { K.Pradheep }\end{array}$ & $\begin{array}{l}\text { A. tetraphyllus } \\
\text { (Roxb. ex Hornem.) Wall. }\end{array}$ \\
\hline Stems & $\begin{array}{l}\text { Dark-green, relatively thin, } \\
\text { hispid }\end{array}$ & Pale green, stout, hispid & $\begin{array}{l}\text { Reddish purple tinged, } \\
\text { relatively thin, scabrous }\end{array}$ \\
\hline $\begin{array}{l}\text { Basal stems } \\
\text { habit }\end{array}$ & Prolific branching, 5-7-branched & Shy branching, 2-3-branched & $\begin{array}{l}\text { Prolific branching, } \\
\text { 4-7-branched }\end{array}$ \\
\hline Basal leaves & Deeply lobed throughout & $\begin{array}{l}\text { Broadly lobed up to mid-point } \\
\text { throughout }\end{array}$ & $\begin{array}{l}\text { Variable, broadly angled up to } \\
\text { mid-point or palmately lobed }\end{array}$ \\
\hline $\begin{array}{l}\text { Epicalyx } \\
\text { (at mature } \\
\text { flower } \\
\text { bud stage) }\end{array}$ & $\begin{array}{l}\text { 4-lobed; lobes deltoid, touches } \\
\text { each other throughout with a } \\
\text { keeled appearance, sparsely ciliate } \\
\text { throughout }\end{array}$ & $\begin{array}{l}\text { 6(7)-lobed; lobes ovate or } \\
\text { elliptic-lanceolate, lobes not } \\
\text { touching each other only at the } \\
\text { top, not keeled, densely ciliate } \\
\text { throughout }\end{array}$ & $\begin{array}{l}\text { 4-5-lobed; lobes broadly } \\
\text { ovate-lanceolate, touching } \\
\text { each other only at the base, } \\
\text { not keeled, softly hairy }\end{array}$ \\
\hline $\begin{array}{l}\text { Epicalyx } \\
\text { covering the } \\
\text { mature fruit }\end{array}$ & Almost full & Just reaching half & $\begin{array}{l}\text { Caducous before fruit } \\
\text { maturity; otherwise reaching } \\
\text { up to } 3 / 4^{\text {th }} \text { length }\end{array}$ \\
\hline Inflorescence & $\begin{array}{l}\text { Axillary lax raceme, clustered } \\
\text { at top without a rosette } \\
\text { appearance }\end{array}$ & $\begin{array}{l}\text { Axillary compact raceme, } \\
\text { clustered at top with rosette } \\
\text { appearance }\end{array}$ & $\begin{array}{l}\text { Terminal, lax, a few-flowered } \\
\text { raceme, without a rosette } \\
\text { appearance }\end{array}$ \\
\hline Corolla colour & $10-14 \mathrm{~cm}$ across, bright yellow & $\begin{array}{l}13.5-14.5 \mathrm{~cm} \text { across, } \\
\text { bright yellow }\end{array}$ & 5-7 cm across, pale yellow \\
\hline Capsules & $\begin{array}{l}\text { Ovoid-ellipsoid, c. } 4.5 \times 1.5 \mathrm{~cm} \text {, } \\
\text { less wide at base }\end{array}$ & $\begin{array}{l}\text { Ovoid, } 6-7.2 \times 2.5-2.8 \mathrm{~cm}, \\
\text { broader at base }\end{array}$ & $\begin{array}{l}\text { Ovoid-oblong, } \\
5-6 \times 1.5-2.0 \mathrm{~cm} \text {, less wide } \\
\text { at base }\end{array}$ \\
\hline
\end{tabular}

Etymology: The epithet 'mizoramensis' refers to the state of Mizoram in northeastern India from where the specimens of this new taxon was collected.

Distribution: Hitherto known only from Mizoram in India.

Specimens examined: INDIA, Mizoram, Bhairavi, 14.10.2011, Joseph John JJK/11-3 (NHCP); Taithow, 16.10.2011, Joseph John JJK/11-2 (NHCP).

Notes: Morphological features helpful in distinguishing $A$. pungens var. mizoramensis from its allies var. pungens and $A$. tetraphyllus are given in Table 1. This taxon grows as a ruderal and also in forest openings and margins of jhoom lands. In its native habitat by the end of November and early December, leaves dry up leaving fruiting stalks with dry capsules in bunches. The persistent epicalyx upon maturity is positioned almost horizontally below the capsule resembling the skirt of a ballet dancer. Even though annual in its native range, under the tropical equatorial climate of Kerala it perennates for over three years. The present taxon was found to be free of Yellow vein mosaic virus (YVMV) symptoms over the years when grown along with susceptible species and okra genotypes. Amphidiploids with okra as maternal parent have been developed and were found to show high level of field resistance to YVMV under Kerala conditions. However, the plants are susceptible to leaf roller caterpillar, African mealy bug, fruit borer and spider mites. The taxon is amenable to cultivation as a rainy season plant. Seeds have 95\% germination and adaptability to agro-climatic conditions of humid tropics. June-sown crop came to flowering by $78^{\text {th }}$ day and completes its life cycle within 100 days. A vigorously growing plant yields 20-25 fruits with an average output of 1000 seeds per plant. New sprouts emerge from the primary 
and secondary branches with the onset of premonsoon rains. Five accessions have been conserved in the National Gene Bank and 18 collections in the Medium Term Storage at RS, Thrissur.

\section{Acknowledgements}

The authors are grateful to Head, Division of Germplasm Evaluation, ICAR-NBPGR and Director, ICAR-NBPGR for the facilities and encouragements. Thanks are due to Dr. V.P. Prasad and Late Dr. P. Lakshminarasimhan, Central National Herbarium, BSI, Kolkata for providing important literature and logistic support in herbarium study at CAL. We are also thankful to the Curator, BR for permitting us to use the digital image of Hibiscus pungens Roxb. The herbarium and field study were carried out with the funding from National Agricultural Innovation Project (ICAR) on 'Biosystematics of the genera Vigna, Cucumis and Abelmoschus'.

\section{Literature Cited}

ANONYMOUS 1991. International Crop Network Series. Report of an International Workshop on Okra Genetic Resources, held at NBPGR New Delhi, India, 8-12 October, 1990. IBPGR, Rome.

HOCHREUTINER B.P.G. 1924. Genres nouveaux et genres discutés de la famille des Malvacées. Candollea 2: 79-90.

JOHN J.K., SCARIAH S., NISSAR V.A.M., BHAT K.V. \& S.R. YADAV 2013. Abelmoschus enbeepeegearensis sp. nov. (Malvaceae), an endemic species of okra from Western Ghats, India. Nordic Journal of Botany 31(2): 170-175.

MISRA R.C., PANI D.R., BHARATHI L.K. \& S.P. AHLAWAT 2018. Abelmoschus angulosus var. mahendragiriensis (Malvaceae): a new taxonomic variety of wild okra from Eastern Ghats of India. Genetic Resources and Crop Evolution 65: 993-1002. https:// doi.org/10.1007/s10722-017-0590-5

OCHSE J.J. \& R.C. BAKHUIZEN VAN DER BRINK 1931. Vegetables of the Dutch East Indies (edible tubers, bulbs, rhizomes and spices included); survey of the indigenous and foreign plants serving as pot-herbs and side-dishes. A. Asher \& Co., Amsterdam.
PATIL P., MALIK S.K., SUTAR S., YADAV S., JOHN J.K. \& K.V. BHAT 2015a. Taxonomic importance of seed macro and micro-morphology in Abelmoschus (Malvaceae). Nordic Journal of Botany 33(6): 696-707. https://doi.org/10.1111/njb.00771.

PATIL P., SUTAR S., JOHN J.K., MALIK S., RAO S., YADAV S.R. \& K.V. BHAT 2015b. A systematic review of the genus Abelmoschus (Malvaceae). Rheedea 25(1): 14-30.

PAUL T.K. 1993. Malvaceae. In: SHARMA B.D., SANJAPPA M. \& N.P. BALAKRISHNAN (eds.), Flora of India, Volume. 3. Botanical Survey of India, Kolkata. pp. 257-394.

PAUL T.K. \& M.P. NAYAR 1988. Malvaceae. In: NAYAR M.P., K.THOTHATHRI \& M. SANJAPPA (eds.), Flora of India, Fascicle 19. Botanical Survey of India, Kolkata. pp. 61-73.

SIVARAJAN V.V. \& A.K. PRADEEP 1996. Malvaceae of Southern Peninsular India: a taxonomic monograph. Daya Publishing House, Delhi.

ROXBURGH W. 1832. Flora Indica or The descriptions of Indian Plants. Volume 3.W. Thacker, Serampore.

SUTAR S., PATIL P., AITAWADE M., JOHNJ., MALIK S., RAO S., YADAV S.R. \& K.V. BHAT 2013. A new species of Abelmoschus Medik. (Malvaceae) from Chhattisgarh, India. Genetic Resources and Crop Evolution 60: 1953-1958. https://doi.org/10.1007/ s10722-013-0023-z.

VAN BORSSUM WAALKES J. 1966. Malesian Malvaceae revised. Blumea 14: 1-213.

VOIGT J.O. 1845. Hortus Suburbanus Calcuttensis: a catalogue of the plants which have been cultivated in the Hon. East India Company's Botanical Garden, Calcutta, and in the Serampore Botanical Garden, generally known as Dr. Carey's Garden, from the beginning of both establishments (1786 and 1800) to the end of August 1841. Kolkata.

WALLICH N. 1829. A Numerical List of dried specimens of plants in the East India Company's Museum: collected under the superintendence of Dr.Wallich of the Company's Botanic Garden at Calcutta. London.

YADAV S.R., BHAT K.V., LATHA M., JOHN K.J., AITWADE M., RAO S.R., SCARIAH S., NISSAR M., UMDALE S., PATIL P., KRISHNAN G. \& R. KHEDSANA 2014. An illustrated guide for the identification of Vigna Savi, Cucumis L. and Abelmoschus Medik. species in India. NBPGR, New Delhi; Shivaji University, Kolhapur and North Eastern Hill University, Shillong. 